\title{
Related Donor Adenovirus-specific Cytotoxic T Cells
}

National Cancer Institute

\section{Source}

National Cancer Institute. Related Donor Adenovirus-specific Cytotoxic T Cells. NCI

Thesaurus. Code C152980.

A population of allogeneic related donor cytotoxic T-lymphocytes (CT Ls) specifically reactive to human adenovirus (Ad) with potential immunomodulating and anti-adenoviral activities. Upon infusion of related donor Ad-specific CT Ls, these cells help reconstitute Ad-specific CT L responses in patients at risk of developing Ad infections after allogeneic stem cell transplant or in Ad-infected immunocompromised hosts. These related donor Ad-specific CT Ls are manufactured with the CliniMACS Prodigy Cytokine Capture System which facilitates production of the Ad-specific CT Ls. 